\title{
PENGETAHUAN IBU TENTANG MENOPAUSE DI POLIKLINIK BLU RSU PROF. DR. R. D. KANDOU MANADO
}

\author{
${ }^{1}$ Inri Suryani Batan \\ ${ }^{2}$ Maya Mewengkang \\ ${ }^{3}$ Hermie M. M. Tendean
}

\author{
Bagian/SMF Obstetri dan Ginekologi RSU Prof. Dr. R. D. Kandou Manado \\ Email: inri_91@yahoo.com
}

\begin{abstract}
The age of menopause in each women is different. When a women encounters the menopause, there will be a physiological and psychological change. If a women receive excellent information about menopause, the psychological change will appear minimal. The incidence of menopause and climacterium is often not considered by most women as important issue. This mindset mostly caused by the consideration that the menopause is a natural process, but some women consider that menopause is a horrible situation. This less attention in menopause is mostly caused by minimal knowledge of women about menopause. This research aims to find out how the mother's knowledge about menopause in Polyclinic BLU RSU Prof. Dr. R. D. Kandou Manado. Research using desciptive with survey method using the questionnaire. The sampling technique used in this research is purposive sampling. Research in was commited in Obstetric-Gynecologic Polyclinic in November 2012. The number of respondents are 50 subjects. The respondents with good knowledge about menopause are 30 subjects (60\%), the respondents who encompass the age group of 35-39 years old are 11 subjects $(78,6 \%)$, the respondents who work as PNS are 10 subjects $(100 \%)$, the respondents who graduated in university are 11 subjects $(100 \%)$ and the information resource of menopause from health care officer are 11 subject (84,6\%). Conclusion: Respondents with good knowledge about menopause are 30 subjects (60\%), and the respondents with minimal knowlegde of menopause are 20 subjects (20\%).
\end{abstract}

Keywords: knowledge, menopause.

\begin{abstract}
Abstrak: Usia menopause pada tiap wanita berbeda-beda. Saat wanita mengalami menopause, terjadi perubahan fisiologik dan perubahan kejiwaan. Apabila wanita mendapat informasi yang baik maka perubahan kejiwaan menjadi minim. Peristiwa menopause dan klimakterium sering tidak menjadi perhatian bagi kebanyakan wanita karena dianggapnya sebagai peristiwa alami, namun sebagian kecil mengganggapnya sebagai sesuatu yang buruk. Hal ini dikarenakan dasar pengetahuan wanita tentang menopause masih sedikit. Penelitian ini bertujuan untuk mengetahui bagaimana pengetahuan ibu tentang menopause di Poliklinik BLU RSU Prof. Dr. R. D. Kandou Manado. Penelitian bersifat deskriptif melalui metode survei menggunakan kuesioner. Teknik yang digunakan yaitu purposive sampling. Penelitian dilakukan di Poliklinik Obstetri-Ginekologi periode November 2012. Jumlah responden sebesar 50 orang. Responden yang memiliki pengetahuan baik tentang menopause sebanyak 30 orang (60\%), tergolong dalam kelompok umur 35-39 tahun yaitu 11 orang (78,6\%), pada pekerjaan PNS yaitu 10 orang (100\%), pendidikan terakhir lulus perguruan tinggi yaitu 11 orang (100\%), dan sumber informasi menopause dari petugas kesehatan sebanyak 11 orang (84,6\%). Kesimpulan: Responden yang memiliki pengetahuan baik tentang menopause sebanyak 30 orang $(60 \%)$, sedangkan responden yang memiliki pengetahuan tidak baik tentang menopause sebanyak 20 orang (40\%).
\end{abstract}

Kata kunci: pengetahuan, menopause 
Pada hakekatnya menopause adalah proses alami dalam fase kehidupan wanita. Arti istilah menopause adalah saat akhir haid atau mati haid. Sedangkan periode peralihan dari fase reproduksi menuju fase usia tua (senium) disebut fase klimakterium, yang meliputi fase premenopause, perimenopause, menopause, dan pasca menopause. $^{1}$

Pada usia 40 sampai 50 tahun, siklus seksual biasanya menjadi tidak teratur, dan ovulasi sering tidak terjadi. Sesudah beberapa bulan sampai beberapa tahun, siklus terhenti sama sekali. Periode ketika siklus terhenti dan hormon-hormon kelamin wanita menghilang dengan cepat sampai hampir tidak ada disebut sebagai menopause. $^{2}$

Saat masuknya seseorang dalam fase menopause sangat berbeda-beda. Wanita di Eropa tidak sama usia menopausenya dengan wanita di Asia. Faktor genetik kemungkinan berperan terhadap usia menopause. ${ }^{3}$ Ada kecenderungan dewasa ini untuk terjadinya menopause pada umur yang lebih tua. ${ }^{4}$

Pada saat menopause, seorang wanita harus menyesuaikan kembali kehidupannya dari kehidupan yang secara fisiologis dirangsang oleh produksi estrogen dan progesteron menjadi kehidupan yang kosong tanpa hormon-hormon tersebut. Hilangnya estrogen seringkali menyebabkan terjadinya perubahan fisiologis yang bermakna pada fungsi tubuh. ${ }^{2}$ Disertai perubahan kejiwaan yang dialami seorang wanita menjelang menopause. ${ }^{5}$ Pada wanita yang mendapat informasi yang baik dan yang mudah menyesuaikan dengan keadaan, perubahan psikologik ini sangat minim dan bahkan tak berarti, dan hanya mengalami periode ketidakstabilan emosional yang singkat. ${ }^{6}$ Studi yang dilakukan oleh Neugarten menunjukkan pentingnya sistem kepercayaan kultural dan jejaring komunikasi antar wanita dalam perilaku sosial terhadap menopause. Dia menyimpulkan bahwa faktor-faktor sosiokultural seperti mitos dan sistem kepercayaan adalah lebih merupakan faktor instrumental dibanding fisiologis dalam membentuk persepsi wanita tentang menopause, dan bahwa jalan komunikasi yang lebih terbuka di antara para wanita yang sudah menopause akan memaparkan efek negatif dan membuat menopause menjadi peristiwa yang kurang menakutkan.

Menurut United Nation Development Program (UNDP) dalam Human Development Report 2005, pada tahun 2003 angka harapan hidup orang Indonesia rata-rata adalah 66,8 tahun. Dalam laporan tersebut disebutkan pula bahwa dari studi selama tahun 1995-2000, persentase perempuan yang mencapai usia 65 tahun lebih besar jika dibandingkan dengan lakilaki, yaitu sebesar $72,1 \%$ berbanding $63,8 \%{ }^{8}$

Dewasa ini, dengan semakin meningkatnya angka harapan hidup, maka akan semakin banyak perempuan yang akan menghabiskan sebagian besar hidupnya dalam keadaan hipoestrogenik. ${ }^{8}$ Peristiwa menopause, klimakterium dan juga aspek fungsi menstruasi sering tidak menjadi perhatian bagi kebanyakan karena dianggapnya sebagai peristiwa yang alami. ${ }^{6}$ Pada hampir $70 \%$ wanita, proses transisi menuju menopause dilalui tanpa keluhan yang berarti. ${ }^{8}$ Tetapi bagi sebagian kecil peristiwa tersebut dibebani pemikiran yang bukan-bukan. Menopause sering dicap sebagai sesuatu yang buruk, oleh karenanya banyak wanita menghadapinya dengan rasa takut dan cemas. ${ }^{6}$

Seorang wanita yang melihat menopause sebagai sesuatu yang menyusahkan atau membebaskan. Dasar pengetahuan tentang menopause masih sedikit, dimana ditemukan pada kebanyakan studi yang dilakukan pada perempuan kulit putih dari keturunan Eropa Utara tentang pengalaman klimakterik relatif sedikit juga pada wanita dari ras lain. ${ }^{9}$

Berdasarkan uraian diatas, maka penulis merasa tertarik ingin meneliti tentang pengetahuan ibu tentang menopause di Poliklinik BLU RSU Prof. Dr. Kandou Manado. 


\section{Tujuan Penelitian}

Untuk mengetahui bagaimana pengetahuan ibu tentang menopause di Poliklinik BLU RSU Prof. Dr. R. D. Kandou Manado.

\section{METODE PENELITIAN}

Penelitian ini bersifat deskriptif melalui metode survei dengan menggunakan kuesioner. Teknik yang digunakan yaitu purposive sampling. Penelitian dilakukan di Poliklinik ObstetriGinekologi BLU RSU Prof. Dr. R. D. Kandou Manado bulan November 2012 dengan mengambil sampel ibu yang berkunjung di Poliklinik BLU RSU Prof. Dr. R. D. Kandou Manado.

Kriteria sampel terbagi 2 yaitu kriteria inklusi yakni ibu usia 30-40 tahun, haid teratur,belum menopause sedangkan kriteria eksklusi yaitu ibu yang tidak bisa membaca, dan responden tidak bersedia berpartisipasi dalam penelitian.

Variabel penelitian berupa pengetahuan ibu tentang tingkat pengetahuan, umur, pekerjaan, pendidikan terakhir, sumber informasi menopause.

Dalam penelitian ini, instrument yang digunakan selama kegiatan pengumpulan, pengolahan, dan penyajian data berupa informed consent dan lembaran kuesioner yang diberikan pada responden.

Pengumpulan data dilakukan dengan mencari pasien ibu di Poliklinik, kemudian memberikan penjelasan pada masingmasing ibu mengenai tujuan dilakukan penelitian dan bersedia menjadi responden dalam penelitian lalu memberikan kuesioner kepada responden untuk kemudian diisi. Selanjutnya data yang diteliti, dikumpulkan kemudian diolah secara komputerisasi. Data yang terkumpul akan dihitung dan disusun dalam bentuk distribusi frekuensi. Data yang dikumpulkan akan disajikan dalam bentuk tabel distribusi frekuensi dan tulisan.

Tingkat pengukuran pengetahuan responden diukur dengan skala Guttman dimana setiap pertanyaan dengan jawaban ya nilainya $=1$ dan pertanyaan dengan jawaban tidak nilainya $=0$. Kategori pengetahuan responden dibagi 2 yaitu pengetahuan baik bila jumlah nilai $\geq 6$ dari 10 pertanyaan dan pengetahuan tidak baik bila jumlah nilai $\leq 5$ dari 10 pertanyaan.

\section{Batasan operasional}

1. Pengetahuan adalah segala sesuatu yang ibu ketahui mengenai menopause dari berbagai macam informasi.

2. Ibu adalah orangtua perempuan yang berumur 30 sampai 40 tahun yang memiliki haid yang teratur dan belum menopause.

3. Menopause adalah haid yang terakhir pada seorang wanita yang menandakan wanita tersebut tidak akan bisa hamil lagi karena produksi hormon estrogen sudah berkurang atau tidak ada sama sekali.

\section{HASIL PENELITIAN}

Berdasarkan hasil penelitian yang telah dilakukan pada 50 responden ibu yang berkunjung di Poliklinik BLU RSU Prof. DR. R. D. Kandou Manado periode November 2012, diperoleh data yang disajikan dalam bentuk tabel distribusi sebagai berikut:

Dari Tabel 2, didapatkan pengetahuan baik terbanyak tergolong dalam kelompok umur 35-39 tahun yaitu 78,6\%, sedangkan pengetahuan tidak baik terbanyak tergolong dalam kelompok umur 30 - 34 tahun yaitu 55,5\%.

Dari tabel 3, didapatkan pengetahuan baik terbanyak tergolong dalam kelompok pekerjaan PNS, pendeta, karyawan, guru, dan mahasiswa yaitu 100\% tetapi jumlah responden paling banyak diantara 5 pekerjaan tersebut yaitu pekerjaan PNS sehingga ditetapkan PNS memiliki pengetahuan baik terbanyak sedangkan pengetahuan tidak baik terbanyak didapatkan pada pekerjaan ibu rumah tangga yaitu $63,3 \%$.

Pada Tabel 4, diperoleh pengetahuan baik terbanyak tergolong dalam kelompok 
pendidikan terakhir lulus Perguruan Tinggi yaitu $100 \%$, sedangkan pengetahuan tidak baik terbanyak tergolong dalam kelompok lulus SMP yaitu $80 \%$.
Tabel 1. Distribusi Frekuensi Pengetahuan Ibu tentang Menopause di Poliklinik BLU RSU Prof. Dr. R. D. Kandou Manado

\begin{tabular}{lcc}
\hline $\begin{array}{c}\text { Pengetahuan Ibu } \\
\text { tentang } \\
\text { Menopause }\end{array}$ & $\boldsymbol{\Sigma}$ (n) & \% \\
\hline Baik & 30 & 60 \\
Tidak Baik & 20 & 40 \\
\hline
\end{tabular}

Tabel 2. Distribusi Frekuensi Menurut Umur ibu dan Pengetahuan tentang Menopause

\begin{tabular}{|c|c|c|c|c|c|c|}
\hline \multirow{3}{*}{ Umur Ibu } & \multicolumn{4}{|c|}{ Pengetahuan } & \multirow{3}{*}{$\Sigma(\mathrm{n})$} & \multirow{3}{*}{$\%$} \\
\hline & \multicolumn{2}{|c|}{ Baik } & \multicolumn{2}{|c|}{ Tidak Baik } & & \\
\hline & $\mathrm{n}$ & $\%$ & $\mathbf{n}$ & $\%$ & & \\
\hline $30-34$ tahun & 12 & 44,4 & 15 & 55,5 & 27 & 100 \\
\hline 35 - 39 tahun & 11 & 78,6 & 3 & 21,4 & 14 & 100 \\
\hline 40 tahun & 7 & 77,8 & 2 & 22,2 & 9 & 100 \\
\hline
\end{tabular}

Tabel 3. Distribusi Frekuensi Menurut Pekerjaan Ibu dan Pengetahuan tentang Menopause

\begin{tabular}{|c|c|c|c|c|c|c|}
\hline \multirow{3}{*}{ Pekerjaan Ibu } & \multicolumn{4}{|c|}{ Pengetahuan } & \multirow{3}{*}{$\Sigma(\mathbf{n})$} & \multirow{3}{*}{$\%$} \\
\hline & \multicolumn{2}{|c|}{ Baik } & \multicolumn{2}{|c|}{ Tidak Baik } & & \\
\hline & $\mathbf{n}$ & $\%$ & $\mathbf{n}$ & $\%$ & & \\
\hline IRT & 11 & 36,7 & 19 & 63,3 & 30 & 100 \\
\hline PNS & 10 & 100 & 0 & 0 & 10 & 100 \\
\hline Wiraswasta & 4 & 80 & 1 & 20 & 5 & 100 \\
\hline Pendeta & 2 & 100 & 0 & 0 & 2 & 100 \\
\hline Karyawan & 1 & 100 & 0 & 0 & 1 & 100 \\
\hline Guru & 1 & 100 & 0 & 0 & 1 & 100 \\
\hline Mahasiswa & 1 & 100 & 0 & 0 & 1 & 100 \\
\hline
\end{tabular}

Tabel 4. Distribusi Frekuensi Menurut Pendidikan terakhir dan Pengetahuan tentang Menopause

\begin{tabular}{|c|c|c|c|c|c|c|}
\hline \multirow{3}{*}{ Pendidikan terakhir } & \multicolumn{4}{|c|}{ Pengetahuan } & \multirow{3}{*}{$\Sigma(\mathbf{n})$} & \multirow{3}{*}{$\%$} \\
\hline & \multicolumn{2}{|c|}{ Baik } & \multicolumn{2}{|c|}{ Tidak Baik } & & \\
\hline & $\mathbf{n}$ & $\%$ & $\mathbf{n}$ & $\%$ & & \\
\hline Lulus SMP & 1 & 20 & 4 & 80 & 5 & 100 \\
\hline Lulus SMA/SMK & 18 & 52,9 & 16 & 47,1 & 34 & 100 \\
\hline Lulus Perguruan Tinggi & 11 & 100 & 0 & 0 & 11 & 100 \\
\hline
\end{tabular}

Tabel 5. Distribusi Frekuensi Menurut Sumber Informasi Menopause dan Pengetahuan tentang Menopause

\begin{tabular}{lccccccc}
\hline \multirow{2}{*}{$\begin{array}{c}\text { Sumber informasi } \\
\text { menopause }\end{array}$} & \multicolumn{9}{c}{ Baik } & \multicolumn{2}{c}{ Tidak Baik } & \multirow{\Sigma}{*}{$\boldsymbol{\Sigma}$ (n) } & \% \\
\cline { 2 - 5 } & $\mathbf{n}$ & $\mathbf{\%}$ & $\mathbf{n}$ & $\mathbf{\%}$ & & \\
\hline Teman/Tetangga/Keluarga & 15 & 51,7 & 14 & 48,3 & 29 & 100 \\
Koran/TV/Internet & 4 & 66,7 & 2 & 33,3 & 6 & 100 \\
Petugas Kesehatan & 11 & 84,6 & 2 & 15,4 & 13 & 100 \\
Tidak Tahu & 0 & 0 & 2 & 100 & 2 & 100 \\
\hline
\end{tabular}


Dari tabel diatas, didapatkan pengetahuan baik terbanyak berdasarkan sumber informasi menopause dari Petugas Kesehatan yaitu sebesar $84,6 \%$, sedangkan pengetahuan tidak baik terbanyak didapatkan tidak mendapat sumber informasi menopause dari siapapun atau tidak tahu yaitu sebesar $100 \%$.

\section{PEMBAHASAN}

Berdasarkan tabel 1, distribusi frekuensi pengetahuan ibu tentang menopause di Poliklinik BLU RSU Prof. Dr. R. D. Kandou Manado, didapatkan responden yang memiliki pengetahuan kategori baik sebanyak 30 orang (60\%), sedangkan responden dengan pengetahuan kategori tidak baik tentang menopause sebanyak 20 orang (40\%). Hasil penelitian ini sesuai dengan hasil penelitian yang dilakukan Effendy dan Mirza Adriana pada tahun 2009 pada 30 responden dengan judul Gambaran Pengetahuan, Sikap, dan Perilaku Perempuan Dalam Menghadapi Menopause Di Kelurahan Ledeng RW 01 Kotamadya Bandung diketahui bahwa hasil penelitian menunjukkan pengetahuan cukup (63,7\%), sikap kurang(60,0\%), perilaku baik (56,7\%). ${ }^{10}$ Pengetahuan yang baik pada seseorang bisa didapatkan dari berbagai macam informasi. Informasi tentang menopause bisa didapatkan dari manapun seperti cerita yang banyak beredar di kalangan para ibu yang sudah mengalami menopause disertai dengan semakin canggihnya teknologi informasi yang membantu pemahaman tentang menopause. Pengetahuan wanita tentang menopause membantu mereka dalam memahami proses-proses serta dampak yang akan dialami ketika menopause. Semakin paham mereka tentang menopause, maka mereka akan tahu bagaimana bersikap terhadap keadaan tersebut. $^{11}$ Sementara itu pada 20 responden yang memiliki pengetahuan tidak baik dikarenakan banyak ibu yang beranggapan menopause merupakan hal yang alami sehingga tidak menganggap penting pengetahuan menopause, menopause dianggap sebagai hal yang tabu untuk dibicarakan secara terbuka ${ }^{12}$ dan ada kalanya sikap kurang mau tahu tentang menopause karena belum mengalami menopause. Berdasarkan survey pendahuluan dari 5 wanita yang di wawancara dari penelitian Ratna Malawat tahun 2010 dengan judul Pengaruh Pendidikan Kesehatan Tentang Menopause Terhadap Tingkat Pengetahuan Wanita Menopause di Pedukuhan Geblagan Tamantirto Kasihan Bantul, mengatakan kalau menopause sering dianggap sebagai hal yang menakutkan dalam kehidupan, selain itu juga mereka tidak mengetahui cara-cara untuk mengatasi atau untuk meminimalisir keluhan - keluhan yang terjadi, juga adanya ketakutan-ketakutan tersendiri, kecemasan yang timbul karena minimnya informasi dan pengetahuan akan menopause serta perubahan yang terjadi karena adanya beberapa mitos terutama mitos negatif yang muncul. ${ }^{13}$

Dari tabel 2, didapatkan pengetahuan baik terbanyak masuk dalam kelompok umur 35-39 tahun yaitu 78,6\%, sedangkan pengetahuan tidak baik terbanyak tergolong dalam kelompok umur 30-34 tahun yaitu 55,5\%. Pada penelitian Ignatius Warsino tahun 2004 yang menyatakan bahwa responden yang mengalami menopause ketika berumur antara 45-50 tahun mempunyai risiko lebih mudah beradaptasi pada menopause dibandingkan dengan responden yang pada saat menopause berumur lebih dari 50 tahun. $^{14}$ Jika dibandingkan penelitian tahun 2004 tersebut dengan hasil penelitian sekarang, terlihat bahwa responden umur 35-39 mulai beradaptasi dengan mencari tahu gejala menopause lewat berbagai macam informasi sehingga pengetahuan mereka menjadi bertambah sedangkan pada kelompok umur 30-34 tahun karena jauh dari usia menopause menyebabkan keingintahuan tentang menopause masih kurang.

Pada tabel 3, didapatkan pengetahuan baik terbanyak tergolong dalam kelompok pekerjaan PNS yaitu 100\%, sedangkan pengetahuan tidak baik terbanyak tergolong 
dalam kelompok ibu rumah tangga sebesar 63,3\%. Adanya pekerjaan pada seseorang memang membutuhkan banyak waktu dan tenaga, namun secara tidak langsung pekerjaan turut andil dalam mempengaruhi tingkat pengetahuan seseorang, seperti hasil penelitian ditemukan bahwa responden dengan pekerjaan PNS memiliki tingkat pengetahuan baik. Ini sesuai dengan penelitian Erni Dewi Y. Tambunan yaitu responden yang bekerja sebagai PNS memiliki informasi yang baik karena banyak berinteraksi dengan orang lain, rajin membaca majalah dan lain lain. $^{15}$ Sedangkan menurut Darmojo dan Hadi yang dikutip oleh N. I. Aprillia dan N. Puspitasari yaitu seorang wanita yang mempunyai aktivitas sosial di luar rumah akan lebih banyak mendapat informasi baik misalnya dari teman bekerja atau teman dalam aktivitas sosial. ${ }^{16}$ Sementara pada kelompok ibu rumah tangga yang memiliki pengetahuan tidak baik sesuai dengan penelitian Rijanto dan Ria Rizki Astalina yakni ibu rumah tangga pada dasarnya mempunyai masalah dalam memperoleh sumber informasi, karena walaupun hanya sebagai ibu rumah tangga, mereka tetap sibuk dengan segala kegiatannya, di antaranya mengurus anak, suami, dan kegiatan rumah tangga lainnya. Selain itu dapat dikarenakan ibu rumah tangga tidak mempunyai minat dan tidak merespon sesuatu yang bersifat sebagai informasi pengetahuan. Walaupun informasi itu ada disekitar responden yang berupa TV, radio, majalah dan koran. ${ }^{17}$

Selain itu ditabel 4, distribusi frekuensi menurut pendidikan terakhir diperoleh pengetahuan baik terbanyak pada responden yang lulus Perguruan Tinggi yaitu $100 \%$, sedangkan pengetahuan tidak baik terbanyak tergolong dalam kelompok lulus SMP yaitu 80\%. Penelitian ini sesuai dengan penelitian Rijanto dan Ria Rizki Astalina bahwa semakin tinggi pendidikan seseorang, maka makin mudah menerima informasi sehingga makin banyak pula pengetahuan yang dimiliki, sebaliknya pendidikan yang kurang akan menghambat sikap seseorang terhadap nilai-nilai yang baru diperkenalkan sehingga informasi yang didapatnya juga kurang. ${ }^{17}$

Berdasarkan tabel 5 diatas, didapatkan pengetahuan baik terbanyak berdasarkan sumber informasi menopause dari petugas kesehatan yaitu 84,6\%, sedangkan pengetahuan tidak baik terbanyak yaitu yang tidak mendapat sumber informasi menopause dari siapapun atau tidak tahu sebesar 100\%. Hal ini sesuai dengan penelitian Erna Rahmayanti pada tahun 2005 yang menyimpulkan bahwa tingkat pengetahuan dan sikap ibu tentang klimakterium akan mempengaruhi tindakan preventif wanita menjelang menopause. Penyuluhan seputar klimakterium dan diskusi-diskusi tentang menopause yang dipandu oleh petugas kesehatan akan sangat baik jika dilakukan. ${ }^{18}$

\section{SIMPULAN}

Dari 50 responden, dapat diidentifikasikan bahwa responden yang memiliki pengetahuan baik tentang menopause yaitu sebanyak 30 orang (60\%), sedangkan responden yang memiliki pengetahuan tidak baik tentang menopause yaitu sebanyak 20 orang (40\%).

\section{UCAPAN TERIMA KASIH}

Terima kasih kepada dr. Juneke J. Kaeng, Sp.OG(K) dan dr. B. Joel Laihad, Sp.OG(K) sebagai Dosen Penguji II dan Dosen Penguji III, dan kepada semua pihak yang secara langsung dan tidak langsung telah menemukan gagasan pada penulisan artikel ini.

\section{DAFTAR PUSTAKA}

1. Biben A. Pemberdayaan perempuan menopause alami menuju menua sehat dengan memanfaatkan panca daya alam. MOGI 2003;27:80-95

2. Guyton AC, Hall JE. Fisiologi wanita sebelum kehamilan dan hormon-hormon wanita. Rachman LY, Hartanto $\mathrm{H}$, Novrianti A, Wulandari N, editors. Buku ajar fisiologi kedokteran. Jakarta: EGC;2007,(11),h.1076. 
3. Baziad A. Menopause dan andropause. Jakarta: Yayasan Bina Pustaka Sarwono Prawirohardjo;2003,h.1-3,5,7,8,30.

4. Wiknjosastro $\mathrm{H}$, Saifuddin $\mathrm{AB}$, Rachimhadhi T. Wanita dalam berbagai masa kehidupan. Wiknjosastro $\mathrm{H}$, editor. Ilmu kandungan. Cet.7. Jakarta: PT Bina Pustaka Sarwono Prawirohardjo;2009,(2),h.130.

5. Manuaba IAC, Manuaba IBGF, Manuaba IBG. Memahami kesehatan reproduksi wanita. Ester M, editor. Ed. 2. Jakarta: EGC;2009,h.217,229.

6. Martono $\mathrm{H}$, Pranarka $\mathrm{K}$, editors. Buku Ajar Boedhi-Darmojo geriatri. Cet. 1. Jakarta: Balai Penerbit FKUI;2009,(4), h.608-9,612-5,617-9.

7. Soedirham O, Sulistyowati M, Devy SR. Faktor-faktor yang mempengaruhi perempuan dalam menghadapi menopause. J. Penelit. Med. Eksakta. 2008;7:h.78.

8. Soewondo P. Menopause, andropause dan somatopause perubahan hormonal pada proses menua. Sudoyo AW, Setiyohadi B, Alwi I, K Marcellus Simadibrata, Setiati S, editors. Buku ajar ilmu penyakit dalam. Jilid III. Jakarta: Interna Publishing;2009,(5),h.2078-80.

9. Wenger NK, Paoletti R, Lenfant CJM, Pinn VW, Connor EB, Birkhauser $\mathrm{MH}$, et al. International position paper on women's health and menopause: a comprehensive approach. NIH PUBLICATION No. 02-3284. July 2002:h.7.

10. Effendy, Adriana M. Gambaran Pengetahuan, Sikap, dan Perilaku Perempuan Dalam Menghadapi Menopause Di Kelurahan Ledeng RW 01 Kotamadya Bandung Tahun 2009 [Tesis]. Universitas Kristen Maranatha.

11. Widyawati A. Hubungan Antara Tingkat Pengetahuan Tentang Menopause Dengan Kecemasan Dalam Menghadapi
Menopause Pada Ibu-Ibu Di Kelurahan Bulan Kecamatan Wonosari Kabupaten Klaten [Skripsi]. Fakultas Ilmu Kesehatan Universitas Muhammadiyah Surakarta.2012.h.50,57.

12. Mackenzie R. Menopause: tuntutan praktis untuk wanita. Jakarta: Arcan;1992,h.2,4,5.

13. Malawat R. Pengaruh Pendidikan Kesehatan Tentang Menopause Terhadap Tingkat Pengetahuan Wanita Menopause di Pedukuhan Geblagan Tamantirto Kasihan Bantul [Skripsi]. Fakultas Kedokteran dan Ilmu Kesehatan Universitas Muhammadiyah Yogyakarta. 2010,h.3.

14. Warsino I. Hubungan karakteristik individu dengan adaptasi menopause di klinik menopause Rumah Sakit Pusat Angkatan Darat Gatot Soebroto Jakarta tahun 2004 [Tesis]. Universitas Indonesia. Agustus 2004,h.64.

15. Tambunan EDY. Gambaran pengetahuan dan sikap wanita usia 40-50 tahun tentang menopause di wilayah kerja Puskesmas Sigumpar Kabupaten Toba Samosir Tahun 2010 [Skripsi]. Universitas Sumatera Utara.

16. Aprillia NI, Puspitasari N. Faktor yang mempengaruhi tingkat kecemasan pada wanita perimenopause. The Indonesian Journal of Public Health, Vol. 4, No. 1, Juli 2007:h.41.

17. Rijanto, Astalina RR. Gambaran Pengetahuan Ibu Menopause tentang Potensi Seksual di RW 02 Kelurahan Tanah Kalikedinding Surabaya. Jurnal Penelitian Kesehatan Suara Forikes. Januari 2011;2:h.55.

18. Rahmayanti E. Hubungan tingkat pengetahuan dan sikap tentang klimakterium dengan tindakan preventif wanita menjelang menopause di Kelurahan Selomartani Kecamatan Kalasan tahun 2005 [Skripsi]. 